\title{
RESENHA CRÍTICA: SIMÕES, Antonio José Ferreira. Integração: sonho e realidade na América do Sul. Brasília: Funag, 2011.
}

CRITICAL REVIEW: SIMÕES, Antonio José Ferreira. Integração: sonho e realidade na América do Sul. Brasília: Funag, 2011.

Heitor Pergher ${ }^{1}$

\section{RESUMO}

A obra do embaixador Simões apresenta a visão pessoal de um ilustre membro da carreira diplomática sobre o processo de integração regional da América do Sul. Fica evidenciado que a integração na região ainda passa por inúmeros percalços, mas, ao mesmo tempo, tem apresentado grandes avanços. Nesse sentido, a integração energética, o combate do tráfico e a democracia são essenciais.

Palavras-chave: Integração; América do Sul; solidarismo.

\section{ABSTRACT}

The work of the ambassador Simões presents a personal view of an illustrious member of the diplomatic career on the process of regional integration in South America. It is evident that the integration in the region still goes through numerous setbacks, but at the same time, has seen large advances. In this sense, energy integration, combating trafficking and democracy are essential.

Key-words: Integration; South America; Solidarism.

A obra Integração: sonho e realidade na América do Sul, do embaixador Antonio José Ferreira Simões, apresenta, através de uma compilação de alguns de seus textos, uma proposta audaciosa. Simões oferece, ao mesmo tempo, uma análise sobre os avanços e limitações do processo de integração na América do Sul, e demonstra, ainda, as razões que levam o Brasil a buscar, de forma tão tenaz, essa maior aproximação com os países da região.

\footnotetext{
${ }^{1}$ Mestrando em Relações Internacionais, UFSC, Florianópolis, Brasil. Conjuntura Global, Vol. 4, n. 1, jan./abr., 2015, pp. 66-69.
} 
O seu livro expõe duas hipótese fundamentais, que remetem ao discurso oficial recorrentemente utilizado pelo Ex-ministro das Relações Exteriores - Celso Amorim. A primeira, é que para o Brasil, a integração da América do Sul não é uma opção, mas sim uma obrigação imposta pela sua própria localização geográfica. A segunda hipótese é que essa integração deve ocorrer através do que se alcunha "solidarismo pragmático".

Para o autor, esse comprometimento natural e obrigatório com a integração sulamericana é mais bem entendido quando se leva em consideração que a "[...] geografia determina nossa posição no mundo, impõe a proximidade física com os vizinhos e torna a região uma dimensão incontornável de nossa política externa (SIMÕES, 2011, p. 50)". Assim, segundo Simões, ao Brasil não resta outra opção, senão se integrar aos seus vizinhos.

Ressalta, porém, que a integração proposta pelo Brasil não é meramente mercantilista, mas também solidária. Assim, a visão do Itamaraty para a região se dividiria entre uma pragmática, que busca a viabilização de negócios e investimentos e uma solidária, que buscaria a diminuição das assimetrias regionais.

Dessa forma, o autor atribui ao Brasil o papel de grande propulsor do processo de integração da região e de ator fundamental na diminuição das assimetrias, devendo assumir as suas obrigações de país pagador. Evidencia-se, assim, o quanto atrelado ao Brasil e à sua política externa estão os avanços e retrocessos do processo de integração na América do Sul. Em suma, para que haja uma América do Sul realmente integrada é necessária a participação ativa do Brasil no adensamento das negociações, na diminuição das assimetrias e no pagamento dos custos da integração.

Ao tratar de forma mais pormenorizada o processo de integração, Simões aborda três temáticas que considera fundamentais: o tráfico internacional de drogas, a integração energética e a importância da redemocratização.

Sobre a questão das drogas, afirma que esta é uma das facetas do processo de integração que mais necessita de soluções duradouras através da cooperação dos países da região, tanto na repressão ao crime como na coibição do tráfico internacional. Defende que o enfretamento do problema deve ser encarado de maneira coordenada em todos os elos da cadeia, como na demanda, produção, tráfico, distribuição, desvio de precursores químicos e outras substâncias utilizadas na produção, lavagem de ativos e 
demais delitos conexos. Ou seja, deve-se ir além da abordagem atual, que prioriza somente o combate à produção das drogas.

A integração energética é estudada principalmente a partir de 2007, quando foi criado o Conselho Energético Sul-Americano. 0 autor expõe a ideia de que a integração energética é capaz de gerar sinergia, que pode ser entendida como um processo que favorece o efeito spill-over. Ou seja, a integração energética tem a capacidade de provocar grandes impactos em outras áreas, estimulando a integração produtiva, comercial, econômica e política. Nesse sentido, é importante lembrar que a integração da Europa teve início através da Comunidade Econômica do Carvão e do Aço - CECA, gerando processos de transbordamento para várias outras matérias que hoje constituem a União Europeia.

A terceira temática é a redemocratização por que passou a região na década de 80, que é entendida como um ponto de mudança fundamental na percepção do processo de integração. Nesse momento, segundo Simões, ocorre maior participação da sociedade civil na formulação da política externa brasileira, principalmente para questões de integração regional. Assim, para o autor, é possível se falar em incentivos societais que propulsionaram a aproximação em várias temáticas dos países sul-americanos a partir, principalmente, de meados da década de oitenta.

Uma característica fundamental e histórica da integração da América do Sul, que bem foi apresentada pelo autor, é o surgimento de um quadro institucional altamente complexo e variado, ou seja, de uma integração que se apoia em múltiplas instituições regionais como: Mercosul, Can, Caricom, Sica, Unasul, Celac, Calc, Grupo do Rio, Alba, Alalc, Aladi e tantas outras. Simões entende essa proliferação de instituições como um fenômeno benéfico para a região, que propicia a integração em vários níveis e temáticas. Assim, descarta a ideia de que estaríamos assistindo "[...] a uma disputa por espaços de poder entre países com diferentes visões de mundo e projetos de inserção internacional (SIMÕES, 2011, p. 45)". O projeto integracional que aqui se desenvolveu, mesmo que diferente do observado na Europa, é um método eficaz de integração e, mais importante, é um projeto da região, representando as possiblidades e necessidades da América do Sul.

A ideia central que permeia todo o seu trabalho é que o Brasil busca, além da sua projeção internacional, garantir a capacidade da região de resolver os seus próprios Conjuntura Global, Vol. 4, n. 1, jan./abr., 2015, pp. 66-69. 
problemas internamente, sem a ingerência de potências externas. Para isso, a Unasul, juntamente com o Conselho de Defesa, o Banco do Sul e outras organizações regionais, tem se demonstrado fundamental, criando uma instituição guarda-chuva capaz de abrigar e coordenar os processos integracionais das mais variadas temáticas, que se desenrolam em diferentes velocidades. A Unasul tem tido sucesso em harmonizar e estimular o desenvolvimento do peculiar modelo de integração Sul-Americano, concedendo espaço para outras instituições regionais atuarem de forma mais específica, eficaz e complementar na integração da América do Sul.

O livro do embaixador Simões, talvez pela clareza do texto, talvez por apresentar a visão pessoal de um ilustre membro da carreira diplomática, que teve muitos anos de sua vida na vanguarda do processo de integração regional, logra sucesso na sua análise e proposta. A sua obra é de grande valia tanto aos profissionais da carreira diplomática e atuantes diretos do processo de integração, como aos acadêmicos e entusiastas interessados em melhor compreender o processo de integração da América do Sul. 